\title{
The effects of online marketing on financial performance in the textile industry
}

DOI: $10.35530 / \mathrm{IT} .071 .03 .1826$

MIHAI CRISTIAN ORZAN

MARGARETA STELA FLORESCU

OCTAV IONUT MACOVEI

\author{
SORIN BURLACU \\ OLGUTA ANCA ORZAN
}

\section{ABSTRACT - REZUMAT}

The effects of online marketing on financial performance in the textile industry

Although Romania has an Internet penetration rate of $73.8 \%$, over the world average, below the European Union average of $85.2 \%$, Romanian Internet users ranked $28^{\text {th }}$ in online shopping, the lowest position in EU, while the Romanian enterprises are the least digital in the EU ranking on the lowest positions in using social media and e-commerce. The aim of this paper is to examine the impact of using online marketing tools in the development and implementation of marketing strategies and their impact on organizational performance in the textile industry. We propose an empirical model, rooted in an in-depth survey of over 897 Romanian organizations acting on the textile industry market (production, distribution or retail), which gives us a general overview of antecedents of online marketing success and its impact on organizational performance.

Keywords: e-commerce, online strategy, online distribution, crowdsourcing, marketing metrics

\section{Influența instrumentelor de marketing online asupra performanței financiare a organizațiilor din industria textilă}

Cu toate că, în România, internetul are o rată de penetrare de 73,8\%, peste media mondială, dar sub media de $85,2 \%$ a ţărilor din Uniunea Europeană, utilizatorii de internet români s-au clasat pe locul 28 la cumpărăturile online, ultima poziție la nivelul UE, în timp ce întreprinderile românești sunt cele mai puțin digitalizate la nivelul UE, fiind pe ultimul loc în utilizarea mediilor sociale şi a comerțului electronic. Scopul lucrării este de a analiza impactul utilizării instrumentelor de marketing online în elaborarea și implementarea strategiilor de marketing și asupra performanței organizaționale pentru întreprinderile ce activează în industria textilă. Ca urmare a studiului, s-a dezvoltat un model empiric, pe baza unui sondaj cu 897 de respondenţi din organizații românești, care acționează pe piața industriei textile (producție, distribuție sau vânzare cu amănuntul) și care ne oferă o imagine de ansamblu bine definită a succesului marketingului online și a impactului său asupra performanței organizaționale.

Cuvinte-cheie: e-comerţ, strategie online, distribuţie online, crowdsourcing, indicatori ai performanţei

\section{INTRODUCTION}

$21^{\text {st }}$ century is the age of globalization and information society. The interconnections between people, people and organizations and between organizations and organizations are ever increasing. The Internet plays a key role in this evolution of the society, being the word and the key technology of the last two decades. The world Internet penetration rate increase since the year 2000 with $1100 \%$ [1]. More and more word companies and organizations have begun to appreciate and benefit from the advantages that the online environment brings to their marketing activity, regardless of its nature, a trend that also manifests in Romania. The Internet penetration rate in Romania is $73.5 \%$, over the world average but below the European Union average of $85.2 \%$ [1].

A study conducted by Śledziewska et al. for Google [2] showed that Romania is the least digital country in the European Union ranking $28^{\text {th }}$ in the Digital Economy and Society - DESI Index, the last place, revealing problems that hold back the Romanian business sector. Furthermore, Romanian ranked $27^{\text {th }}$, regarding the level of digital skills of the society, outperforming only Bulgaria. Romanian Internet users ranked $28^{\text {th }}$ in online shopping and $27^{\text {th }}$ position in users engaging in online services and online banking. Also, the level of development of Digital Public Services (like e-government) is the second lowest in the European Union (27 $7^{\text {th }}$ place).

The same study shows that Romanian companies and organizations are not using social media, ranking the lowest in the UE at this chapter (28 ${ }^{\text {th }}$ place), and do not take full advantage of other digital tools [2]. Regarding the use of electronic information sharing software, like management tools, Romanian organizations also rank on some of the lowest position: $24^{\text {th }}$ place for software like ERP software and $26^{\text {th }}$ for cloud computing services. Furthermore, Romanian companies and organizations are not engaged in ecommerce, Romania placing on lower positions at 
criteria like the share of firms selling online $\left(24^{\text {th }}\right.$ place), turnover share (24 $4^{\text {th }}$ place) and cross-border selling (28 ${ }^{\text {th }}$ place).

In conclusion, Romanian enterprises are the least digital in the EU and these country's problems with digital transformation affect the business environment. These researches show a lot about the maturity of the online business environment in Romania, which has a great development potential, but much to reach the level of maturity of the most economically developed European states. The aim of this paper is to examine the impact of designing online marketing strategies and implementing online marketing techniques on the financial and marketing performance of Romanians' textile industry organizations in order to explain and predict their intention to continue using online marketing tools to achieve their strategic objectives.

A unique econometric model has been proposed for this study in order to analyze the influence of using online marketing techniques in implementing marketing strategies on the textile industry organizations' financial and marketing performance and their intention to continue using online marketing strategies and techniques.

\section{RESEARCH MODEL AND HYPOTHESES}

The development of online environment implies the adoption of marketing tools in order to achieve the short, medium or long-term strategic objectives. The results of adopting online marketing tools should be reflected in the company's marketing performance and implicitly in their financial performance, including reputation, market share, number of clients, customer loyalty. Thus, some of the research questions we try to answer include:

1. How is the use of online marketing techniques and tools in implementing marketing strategies reflected in the textile industry organization's marketing and financial performance?

2. Can it be said that using online marketing techniques in implementing marketing strategies, will the textile industry organization increase its reputation, market share or number of clients?

3. Furthermore, the mere adoption of online marketing tools does imply the continuity of this decision? As a result, we are proposing the following hypotheses:

- Hypothesis 1: The frequency of using online marketing techniques has a direct and positive effect on the frequency of using online marketing techniques.

Online marketing techniques can be used to implement marketing strategies for the four marketing mix elements: price, product, place, and promotion [3]. Thus, we state that:

- Hypothesis 2-5: The frequency of using online marketing techniques has a direct and positive effect on implementing product (H3-price, H4-place, H5-promotion) marketing strategies.
The link between the use of business strategies and the textile industry organizations' financial performance has been described and verified in many studies, most frequently on the link between Porter's generic strategies used by textile industry organizations and their impact on the financial performance, moderated by the organization's internal and external environment [4-6]. There are many adaptations of this model, one of them regarding the influence of using strategies on the success of online marketing [7]. We hereby formulate the $\mathrm{H} 6-\mathrm{H} 9$ hypotheses of the research:

- Hypotheses 6-9: The frequency of using online marketing techniques in implementing product (H7 - price, H8 - place, H9-promotion) marketing strategies has a direct and positive effect on textile industry organizations' marketing performance.

The marketing performance of the textile industry organization, which combines aspects of increasing the organization's reputation, market share, number of customers and their loyalty, is determined to a lesser or greater extent by the use of online marketing tools, which underpin the implementation of marketing strategies in the online environment.

- Hypothesis 10: The frequency of using online marketing techniques on implementing marketing strategies has a direct and positive effect on textile industry organizations' marketing performance.

- Hypothesis 11: The frequency of using online marketing tools on implementing marketing strategies has a direct and positive effect on textile industry organizations' marketing performance.

A textile industry organization's marketing performance reflects its financial performance: increasing turnover, sales revenue, profits, and leads. In other words, the benefits of using online marketing tools in implementing marketing strategies reflect in the organizations' financial performance [8]:

- Hypothesis 12: Textile industry organizations' marketing performance has a direct and positive effect on organizations' financial performance.

However, developing and implementing online marketing strategies and techniques entails costs for the organization that adopts them. First, it is about spending with qualified staff, because not all employees have knowledge, skills or abilities to develop or implement an online marketing strategy or technique. Second, the development and implementation of online marketing techniques involve the use of technological equipment [9]. The continued use of these techniques involves maintenance costs. All these costs reflect in the company's financial performance and the profit will change:

- Hypothesis 13: The costs of implementing online marketing techniques have a direct and positive effect on textile industry organizations' financial performance.

Relative advantages are a concept taken from Diffusion of Innovation Theory [10]. There is no general rule on the components of the relative advantage 
concept. These depend on the perceptions and specific needs of a user group [10].

Thus, in the present research, the relative advantages of using online marketing strategies and techniques can be reflected in the textile industry organization's financial performance. The extent to which marketers perceive the relative benefits of using online marketing tools to achieve strategic goals depends not only on the adoption rate [10] but also on the continuity of intent [11].

- Hypothesis 14: Textile industry organizations' financial performance has a direct and positive effect on textile industry organizations' intention to continue using online marketing techniques.

Simple adoption of online marketing strategies and techniques does not imply continuity. Marketing decision makers can always give up their use. The basis for this assertion is found in the Theory of Dissemination of Innovation [10], which states that the adoption of innovation can result either in continuity or discontinuity.

The Expectation Confirmation Theory [12] places satisfaction as the main predictor of the behavioural continuity intention. This causal link between satisfaction and intention was validated for individual behaviour in the case of intention to continue shopping online [3], and will be adapted to the study of textile industry organizational behaviour:

- Hypothesis 15: Satisfaction of using online marketing techniques has a direct and positive effect on textile industry organizations' intention to continue using online marketing techniques.

However, decision-makers' satisfaction with their decision to use online marketing strategies and techniques is determined by certain factors. The Expectation Confirmation Theory [12] postulates product performance as a key predictor of the extent to which customers are satisfied with choosing a product. In a similar way, we will assume that the decision makers will be satisfied with their decision to use online marketing tools to the extent that they perceive a higher level of financial performance due to the development and implementation of online marketing strategies and techniques:

- Hypothesis 16: Textile industry organizations' financial performance has a direct and positive effect on organizations' satisfaction of using online marketing techniques.

The textile industry organizations operate in accordance with the evolution of the economic and social environment, which implies the adaptation of the enterprise's activity to the external environment. The company meets customers, the most important component of organization's micro-business. Customers can be the ones who put pressure on the business to adopt online marketing tools or techniques. To substantiate the direct and positive effects of these pressures, we have resorted to the study of the Theory of Behaviour Planned [13], which take into account the social component in the study of the behavioural intent of individuals.

- Hypothesis 17: The level of external pressure has a direct and positive effect on textile industry organizations' intention to continue using online marketing techniques.

Adoption and continued use of information technology closely link to the concept of compatibility. Compatibility is a concept specific to the Diffusion of Innovation Theory [10] and represents "the degree to which innovation is perceived as consistent with past values, experiences, and needs of potential users". Similarly, the variable compatibility was built in the present research. Compatibility implies a concordance between the overall purpose, goals, values and organizational culture of the enterprise, and the use of online marketing strategies and techniques.

- Hypothesis 18: The compatibility with using online marketing techniques has a direct and positive effect on textile industry organizations' intention to continue using online marketing techniques.

\section{METHODOLOGY, DATA ANALYSIS AND RESULTS}

The survey instrument was pretested on a sample of 60 respondents and the questions were adjusted after the reliability and internal consistency analysis. The model contains two types of variables: six variables measured on a frequency scale and seven variables are measured on a 7-point Likert scale ranging from 1 - Strongly disagree to 7 - Strongly agree as shown in figure 1.

The target population consists of all companies and textile industry organizations with a presence in the online environment registered in the Romanian National Trade Register Office. The resulted sample size statistically representative for a confidence interval of $95 \%$ and an error of $+/-3$ has 874 respondents. A survey was conducted on a sample of 944 Romanian textile industry organizations, with 893 entries validated and subjected to further analysis.

In the research, the four steps [14] and double phasing of the analysis process [15] were applied. First, the reliability and internal consistency analysis for variables measured with Likert scales followed that the items corresponding to each construct have a Cronbach's Alpha value over 0.7 [16], the items being accurate and describing well the latent construct (table 1). Next, the average variance extracted (AVE) values from table 1 , which are all over 0.5 , show constructs' good convergent validity and the square roots of AVE are higher than any other correlation among latent variables (table 1), resulting a good discriminant validity [16].

\section{RESULTS AND DISCUSSION}

The proposed research model was analyzed using WarpPLS 6.0 with the bootstrap resampling method. 


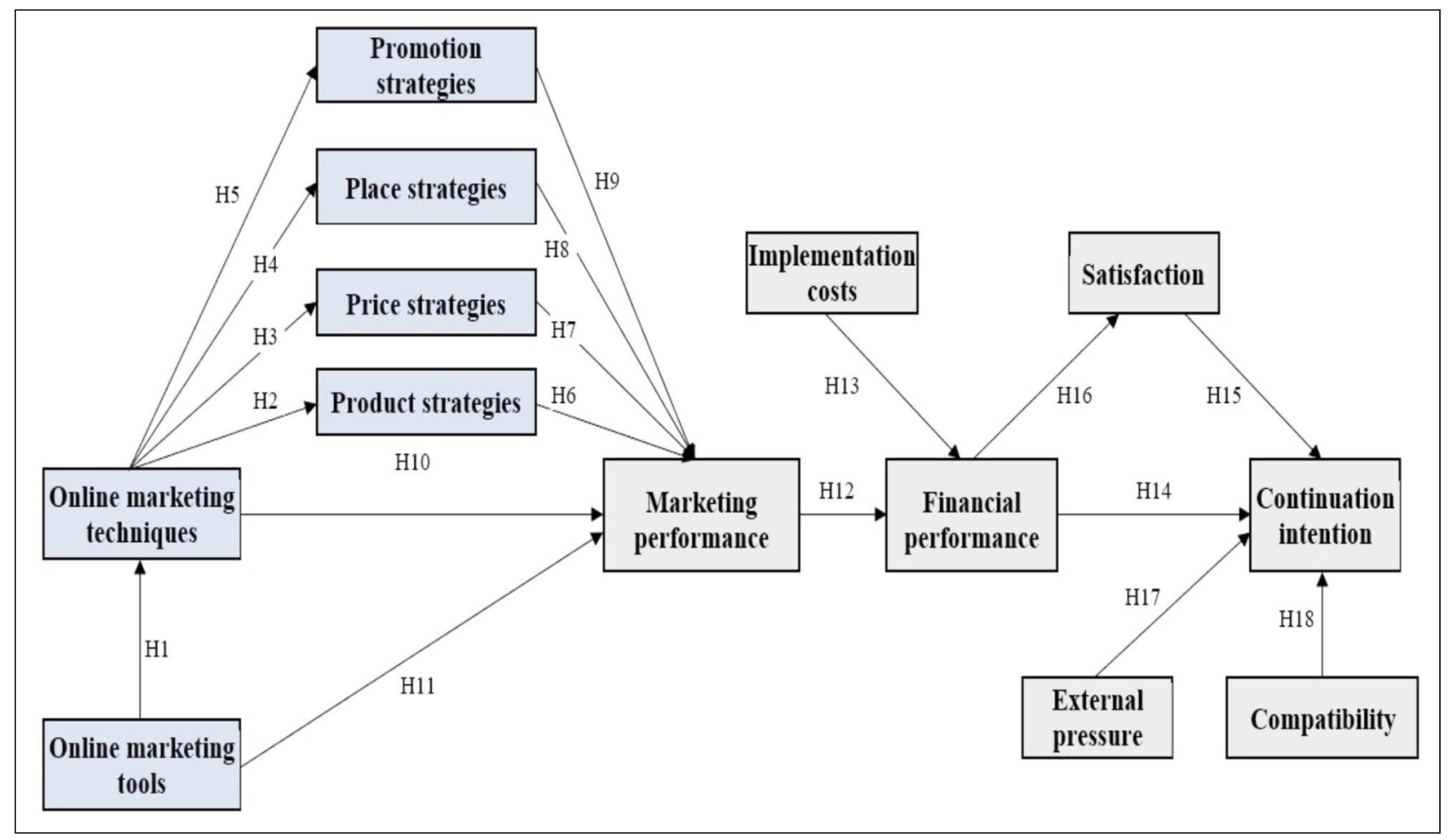

Fig. 1. The research model: the performance model of using online marketing techniques

Table 1

\begin{tabular}{|l|c|c|c|c|c|c|c|c|c|}
\hline \multicolumn{10}{|c|}{ RELIABILITY AND VALIDITY ANALYSIS } \\
\hline \multicolumn{1}{|c|}{ Items } & Alpha & AVE & $\mathbf{1}$ & $\mathbf{2}$ & $\mathbf{3}$ & $\mathbf{4}$ & $\mathbf{5}$ & $\mathbf{6}$ & $\mathbf{7}$ \\
\hline 1. MK_PERF & 0.897 & 0.710 & $\mathbf{0 . 8 4 3}$ & 0.643 & -0.282 & 0.503 & 0.551 & 0.462 & 0.496 \\
\hline 2. FIN_PERF & 0.929 & 0.779 & 0.643 & $\mathbf{0 . 8 8 3}$ & -0.36 & 0.522 & 0.698 & 0.499 & 0.533 \\
\hline 3. COSTS & 0.794 & 0.629 & -0.282 & -0.36 & $\mathbf{0 . 7 9 3}$ & -0.298 & -0.268 & -0.283 & -0.292 \\
\hline 4. SATISFAC & 0.911 & 0.790 & 0.503 & 0.522 & -0.298 & $\mathbf{0 . 8 8 9}$ & 0.645 & 0.572 & 0.502 \\
\hline 5. INTENTIO & 0.899 & 0.832 & 0.551 & 0.698 & -0.268 & 0.645 & $\mathbf{0 . 9 1 2}$ & 0.587 & 0.589 \\
\hline 6. COMPATIB & 0.932 & 0.772 & 0.462 & 0.499 & -0.283 & 0.572 & 0.587 & $\mathbf{0 . 8 7 8}$ & 0.502 \\
\hline 7. EXT_PRES & 0.887 & 0.751 & 0.496 & 0.533 & -0.292 & 0.502 & 0.589 & 0.502 & $\mathbf{0 . 8 6 6}$ \\
\hline
\end{tabular}

Note: Square roots of AVE's shown on diagonal

Figure 2 shows the model's estimates of $\beta$ path coefficients with their probability values and the $R^{2}$ coefficients. Estimates show that textile industry organizations' marketing performance (MKPERF) variance is explained by its six predictors measured on frequency scale in a proportion of $64 \%$, which is very good, the main predictor being the frequency of using online marketing techniques (TECHNIC), with a beta coefficient of 0.30 , followed by the frequency of using online marketing techniques in implementing promotion marketing strategies with a beta path coefficient of 0.22 .

Textile industry organizational financial performance (FINPERF) variable variance is explained by its two predictors variance in a percentage of $47 \%$, the strongest predictor being textile industry organization marketing performance (MKPERF), as expected (beta $=0.57$ ), while the costs of implementing online marketing techniques also manifest an influence of only 0.22 , suggesting that textile industry organizations don't perceive the costs as a strong obstacle in using online marketing techniques. The third most important dependent variable's variance, intention to continue using online marketing techniques (INTENTIO) is explained in a proportion of $63 \%$ by the variance of its four predictors, the strongest being financial performance (FINPERF, beta $=0.38$ ), followed by the mediating variable adapted for the context of business, satisfaction of using online marketing techniques (SATISFAC, beta $=0.26$ ).

All ten models fit and quality indices from table 2 have very good or excellent values and probabilities. The AVIF index, which is the most important measure of the model fit, is 1.224 , under the ideal limit of 3.3 , while the ARS index is 0.291 for a $p<0.001$ [18]. The third most important index, APC, is 0.232 for a $p<0.001$ [18].

In conclusion, our findings validated the proposed model and its research hypotheses. 


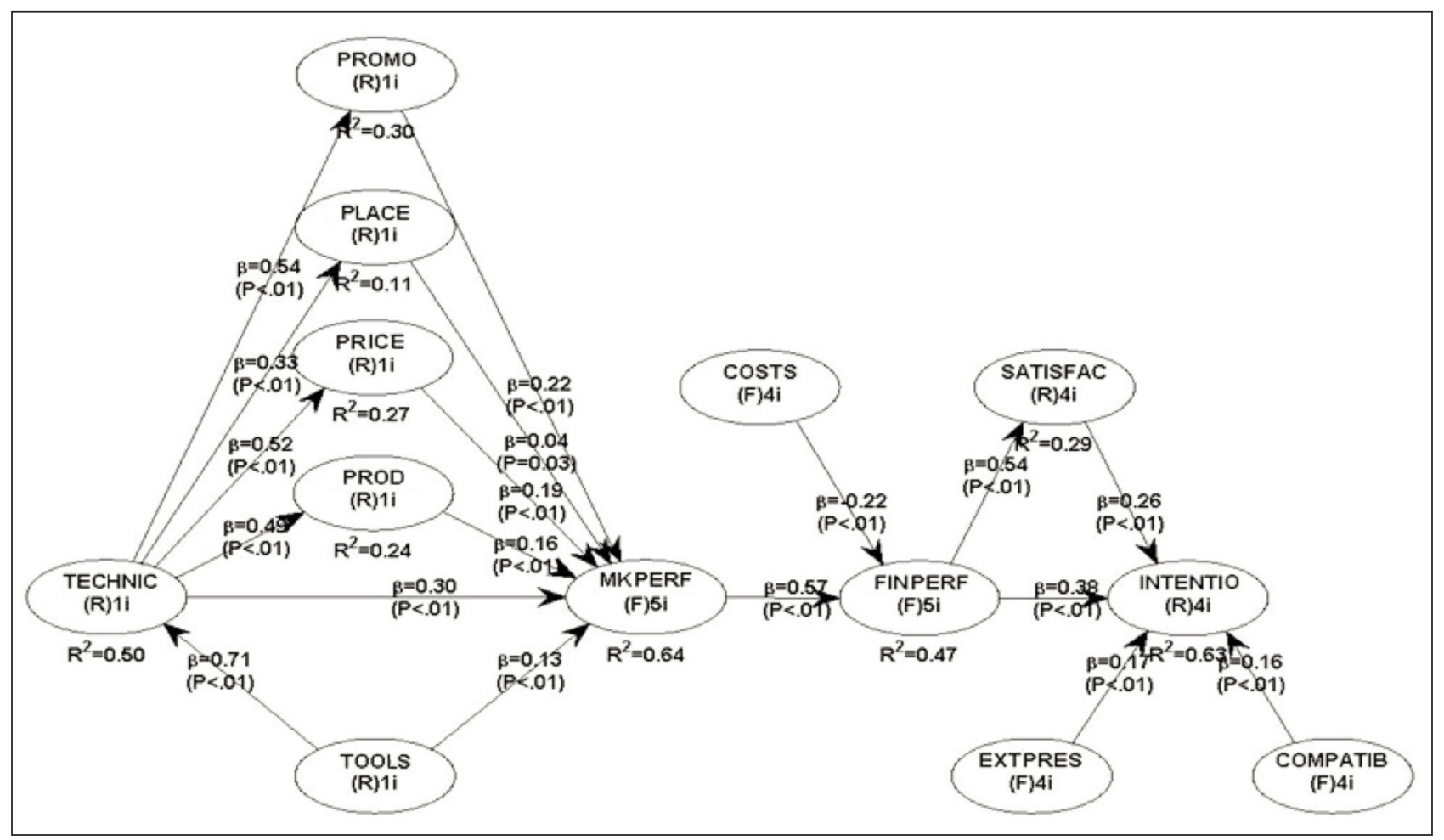

Fig. 2. Estimated model using PLS Analysis

Table 2

MODEL FIT AND QUALITY INDICES (COMPUTED WITH WARPPLS 6.0)

\begin{tabular}{|c|c|}
\hline Indices & Criterion \\
\hline Average path coefficient (APC) $=0.232$ & $P<0.001$ \\
\hline Average R-squared $(A R S)=0.291$ & $P<0.001$ \\
\hline Average adjusted R-squared (AARS) $=0.453$ & $P<0.001$ \\
\hline Average block VIF (AVIF) $=1.224$ & acceptable if $\leq 5$, ideally $\leq 3.3$ \\
\hline Average full collinearity VIF (AFVIF) $=1.879$ & acceptable if $\leq 5$, ideally $\leq 3.3$ \\
\hline Tenenhaus GoF $(\mathrm{GoF})=0.487$ & $\begin{array}{l}\text { small } \geq 0.1 \\
\text { medium } \geq 0.25 \\
\text { large } \geq 0.36\end{array}$ \\
\hline Sympson's paradox ratio $(\mathrm{SPR})=1.000$ & acceptable if $\geq 0.7$, ideally $=1$ \\
\hline R-squared contribution ratio $(\mathrm{RSCR})=1.000$ & acceptable if $\geq 0.9$, ideally $=1$ \\
\hline Statistical suppression ratio $(\mathrm{SSR})=1.000$ & acceptable if $\geq 0.7$ \\
\hline $\begin{array}{l}\text { Nonlinear bivariate causality direction ratio } \\
(\mathrm{NLBCDR})=1.000\end{array}$ & acceptable if $\geq 0.7$ \\
\hline
\end{tabular}

adapted to individual consumer behaviour specific metrics, such as satisfaction, intention to continue the use, compatibility or normative behaviour.

The methodological implications consist mainly in proposing, testing and validating measurement scales such as the financial and marketing performance of textile industry organizations, strategy implementation costs, textile industry organizations' compatibility issues implementing online marketing techniques and external pressure felt by textile industry organizations. These metrics proved to be reliable and can be used in future research.

\section{IMPLICATIONS, CONCLUSIONS AND FURTHER RESEARCH}

In this study, we studied the positive effects of online marketing tools on marketing performance in an emerging economy, as well as their implications on textile industry organizational financial performance. Furthermore, we measured a synergetic effect of online marketing techniques on textile industry organization's marketing and financial performance.

The theoretical implications include introducing new relationships between the thirteen variables adapted for the case of using online marketing techniques by companies and textile industry organizations, as well as novel ways of measuring marketing performance,
The managerial implications consist in establishing the direct and positive effect of the use of online marketing tools in achieving strategic marketing objectives on the marketing and financial performance of the textile industry organizations. From these relationships we can observe that textile industry organizations which are not currently using online marketing tools in implementing their marketing strategies have poor marketing and financial performance and need to adopt them as soon as possible in order to be competitive and survive in the future.

Future research could analyse the relationship between the usage of brand and loyalty strategies in 
the online environment and the textile industry organization's financial performance.

\section{ACKNOWLEDGEMENTS}

This research was supported financially by the project CNFIS-FDI-2018-0582 - Supporting Excellence Research within The Bucharest University of Economic Studies in the context of the principles of sustainable development and open research. 6. Supporting field research excellence in universities Beneficiary: The Bucharest University of Economic Studies.

\section{REFERENCES}

[1] Internet World Stats, Usage and Population Statistics, 2020, Available at: http://www.internetworldstats.com/ stats.htm [Accessed March 2020]

[2] Śledziewska, K., Włoch, R., Akhvlediani, T., Gyódi, K., Zięba, D., Transformation of Small and Medium Enterprises in ROMANIA, CDELab UW - Commissioned by Google, 2020, Available online at: https://www.delab.uw. edu.pl/pl/digital-transformation-of-small-and-medium-enterprises-in-romania/ [Accessed March 2020]

[3] Orzan, G., Iconaru, C., Popescu, I.C., Orzan, M., Macovei, O.I., PLS-based SEM analysis of apparel online buying behavior. The importance of eWOM, In: Industria Textila, 2013, 64, 6, 362-367

[4] Kim, E., Nam, D., Stimpert, J.L., The applicability of Porter's generic strategies in the digital age: Assumptions, conjectures, and suggestions, In: Journal of Management, 2020, 569-589

[5] Allen, R.S., Helms, M.M., Linking strategic practices and textile industry organizational performance to Porter's generic strategies, In: Business Process Management Journal, 2006, 433-454

[6] Georganta, Z., Vogiatzi, M., The Effects of Information and Communication Technologies on E-Business Performance: Designing a Path Analysis Framework, In: Journal of Information Technology Impact, 2010, 10, 3, 137-160

[7] Elliot, R., Rupping, P.T., The Influence of Porter's Generic Strategies on the Success of Internet Marketing, In: Australian \& New Zealand Marketing Academy Conference, 2004, 1-9

[8] Ceptureanu, E.G., Ceptureanu, S.I., Orzan, M.C., Bordean, O.N, Rădulescu, V., Empirical Study on Sustainable Opportunities Recognition. A Polyvinyl Chloride (PVC) Joinery Industry Analysis Using Augmented Sustainable Development Process Model, In: Sustainability, 2019, 9, 10, 420-427, https://doi.org/10.3390/su9101779

[9] Tuta, M., Zara, I.A., Orzan, G., Purcărea, V.L, Orzan, O.A., Competitive Intelligence: An Enhancement to Business Intelligence, In: Economic Computation and Economic Cybernetics Studies and Research, 2014, 48, 2, 151-161, https://doi.org/10.3390/su9101779

[10] Rogers, E.M., Diffusion of Innovations, The Free Press Publishing, New York, 1995

[11] Bhattacherjee, A., Premkumar, G., Understanding changes in belief and attitude toward information technology usage: A theoretical model and longitudinal test, In: MIS Quarterly, 2004, 229-254

[12] Oliver, R.L., A Cognitive Model of the Antecedents and Consequences of Satisfaction Decisions, In: Journal of Marketing Research, 1980, 460-469

[13] Ajzen, I., The Theory of Planned Behavior", In: Organizational Behavior and Human Decision Processes, 1991, 179-211

[14] Morteza, C., Norzima, B.Z., Faieza, A.A., The Interactive Model of User Information Technology Acceptance and Satisfaction in Small and Medium-sized Enterprises, In: European Journal of Economic, Finance and Administrative Sciences, 2010, 19, 181-211

[15] Kline, R.B., Principles and Practice of Structural Equation Modeling (3rd edition), The Guilford Press, New York, USA, 2011

[16] Kock, N., WarpPLS User Manual: Version 6.0. Laredo, TX: Script Warp Systems, 2017

\section{Authors: \\ MIHAI CRISTIAN ORZAN ${ }^{1}$, MARGARETA STELA FLORESCU², OCTAV IONUT MACOVEI ${ }^{1}$, SORIN BURLACU ${ }^{2}$, OLGUTA ANCA ORZAN ${ }^{3}$}

${ }^{1}$ Bucharest University of Economic Studies, Faculty of Marketing, Bd. Dacia, no. 41, 010374, Bucharest, Romania e-mail: octav.macovei@yahoo.com

${ }^{2}$ Bucharest University of Economic Studies, Faculty of Administration and Public Management,

Piața Romana, no. 6, 010374, Bucharest, Romania e-mail: sburlacu@man.ase.ro

${ }^{3}$ Emergency University Hospital Elias, Bd. Mărăşti, no. 17, 011461, Bucharest, Romania e-mail: orzan@yahoo.com

Corresponding author:

MARGARETA STELA FLORESCU

e-mail: margareta.florescu@ari.ase.ro 